\title{
THE EFFECTS OF NUTRITION INTAKE AND PEER ROLE ON OVERWEIGHT AMONG ADOLESCENTS: A PATH ANALYSIS FROM KARANGANYAR, CENTRAL JAVA
}

\author{
Aris Widiyanto',2), Bhisma Murti²), RB. Soemanto3) \\ ${ }^{1)}$ School of Health Sciences Mambaul Ulum, Surakarta \\ 2)Masters Program in Public Health, Universitas Sebelas Maret \\ 3)Faculty of Social and Political Sciences, Universitas Sebelas Maret
}

\begin{abstract}
Background: The adolescent period is associated with changes in eating and activity behaviors. Peer experiences have been theoretically and empirically related to the "Big Two" contributors to the obesity epidemic, unhealthy eating and physical inactivity among adolescents. This study aimed to examine the effects of nutrition intake and peer role on overweight among adolescents.

Subjects and Method: A cross-sectional study was carried out in 25 junior high schools in Karanganyar, Central Java, in December 2017. A sample of 200 students was selected for this study by fixed disease sampling. The dependent variable was overweight. The independent variables were nutrition intake, snacking habit, physical activity, maternal education, family income, and peer role. Data on body weight were measured by weight scale. Data on height were measured by microtoise. The other variables were measured by questionnaire. The data were analyzed by path analysis.

Results: The risk of overweight in adolescents was directly and positively affected by high nutrition intake ( $\mathrm{b}=2.04 ; 95 \% \mathrm{CI}=1.21$ to $2.87 ; \mathrm{p}<0.001)$, high snacking habit $(b=1.28 ; 95 \% \mathrm{CI}=0.43$ to $2.14 ; \mathrm{p}=0.003)$, and strong peer role $(\mathrm{b}=1.98$; $95 \% \mathrm{CI}=1.16$ to $2.81 ; \mathrm{p}<0.001)$, but negatively affected by high physical activity $(b=-2.11 ; 95 \% \mathrm{CI}=-2.95$ to $-1.26 ; \mathrm{p}<0.001)$. The risk of overweight in adolescents was indirectly affected by maternal education and family income.

Conclusion: The risk of overweight in adolescents is directly and positively affected by high nutrition intake, high snacking habit, and strong peer role, but negatively affected by hig physical activity. The risk of overweight in adolescents is indirectly affected by maternal education and family income.
\end{abstract}

Keywords: overweight, nutrition intake, snacking habit, physical activity, maternal education, family income, peer role

\section{Correspondence:}

Aris Widiyanto. STIKES Mamba'ul 'Ulum, Jl. Ring Road Utara, Tawangsari, Mojosongo, Jebres, Surakarta, Central Java.

Email: widiyanto.aris99@gmail.com. Mobile: 081329209095. 